\title{
Lesser Known Indian Women Educators and Reformers
}

\author{
Anasuya Adhikari ${ }^{1}$, Birbal Saha ${ }^{2}$ \\ ${ }^{1}$ Research Scholar \& ${ }^{2}$ Professor, Department of Education, Sidho-Kanho-Birsha University, Purulia, West \\ Bengal, India \\ Corresponding Author: Birbal Saha
}

\begin{abstract}
India can presently be called a leading nation while considering the field of women education. But the scenario was not always the same. Women had to struggle to reach this summit. The path was not easy and smooth. Interestingly enough, eminent women themselves played a crucial role in not only establishing themselves, but also in promoting women's education, health, shelter homes, care for the orphans etc. They established schools and other institutes to promote education to not only the women but also to the weaker section of the society and fight against the injustice. This paper is an attempt to remember few of these eminent women, like Tarabai Modak, Durgabai Deshmukh, Anutai Wagh, Pandita Ramabai, Pandita Brahmacharini Chandbai, Nawab Begum Sultan Kaikhusrau Jahan, who were path breakers in their attempt to transcend the homely domain and set a new milestone. This paper also attempts to credit these noteworthy women for their extraordinary contribution to social services.
\end{abstract}

Keywords: Women Educators, Women Reformers, Female Education, Indian Women

\section{INTRODUCTION}

Indian women were always placed high during the ancient time, till their status declined rapidly with time. With the arrival of the Europeans, new ideas about women's role and capabilities emerged up which was eagerly adopted by the enlightened Indians. Indian texts depicted women as sacrificing and devoted, at the same time occasionally rebellious and dangerous. Miriam Schneir in her book Feminism: The Essential Historical Writings (1972) pens down, "No feminist works emerged from behind the Hindu purdah or out of Moslem harems; centuries of slavery do not provide a fertile soil for intellectual development or expression" (p.xiv). Therefore, it was important for a number of likeminded, progressive women, to come out of the domestic realm to speak and work for themselves. Thus, women stepped out of their domains to transcend into a different world to project themselves, their works and at the same time uplift societal issues dominating women. Their path wasn't easy but they had amazing force of will. Women like Tarabai Modak, Durgabai Deshmukh, Anutai Wagh, Pandita Ramabai, Pandita Brahmacharini Chandbai, Nawab Begum Sultan Kaikhusrau Jahan were some of them, who not only spoke of equality, but also made remarkable attempts to educate and establish women. They believed in the patience and devotion lying within a woman, and that these two qualities could actually do miracles.

These women also concentrated in uplifting the women from the rural and tribal areas. For them, was not only food, cloth, shelter, which were necessary for the survival of a woman, but education was also necessary for a better livelihood and understanding of the world. Hence, they preferred standing beside the oppressed and uplifting them through all possible ways. These remarkable women were trend setters. 
They not only set paths for a new beginning but also, experimented success with it.

\section{TARABAI MODAK}

Tarabai Modak (19 April 1892-31 August 1973) belonged to Mumbai and is often honoured as the 'Montessori Mother'. Her significant contribution to the education in India is noteworthy. Her methods used for the preschool education ushered in a silent revolution constituting the tribal community of Kosbad. In 1921, Tarabai went to become the very first Indian Principal of Barten Female College of Education at Rajkot. Tarabai was highly influenced by Maria Montessori's writings and methods. This made her to decide and experiment the methods to educate her daughter. In 1923, she joined Shri Gijubhai Badheka in Bhavnagar. Gijubhai began with a pre-primary school following Montessori's curriculum. The year 1926 became important since, Tarabai Modak assisted him to establish the Nutan Bal Shikshan Sangh. She also established theGram Bal Shiksha Kendra in 1945 in Bordi, Maharastra.

She was among those Indians who visited Europe to attend the Montessori conference in 1949, held in Italy. Tarabai launched The Vikaswadi Project at Kosbad. A complete 27 years of Tarabai was devoted to this project. She became the General Secretary of the Nutan Bal Shikshan Sangh and continued to be on the chair for the next 25 years. She also authored a number of books devoted to children, parents and child education in English.

The industrialized west provided with an important concept of the practice and organizing formal child education. Madam Montessori's theory of molding children through education transcended from Europe to India unbelievably rapid. The theories of Maria Montessori fascinated Gijubhai Badeka and he began with his Bal Mandir at Bhavnagar, Indianising Montessori method.

Tarabai, the Montessori Mother, is hailed for her zeal and dedication towards promoting pre-primary education, most essentially for the scheduled tribes. Her activities reflected the thinking, mind-set, ideas and interest to run an experimental school at Kosbad, Maharashtra. Tarabai worked hard to promote modern civilization and take it to the doors of the tribal children, developing the sense of belongingness. Her objective was to bring a change to the living standard through education. Tarabai was awarded Padma Bhushan in 1962.

\section{ANUTAI WAGH}

Anutai Wagh born in 1910 was married at the age of 13. But her misfortune made her a widow only 6 months after her marriage, after which she returned to her parents' home. Her struggle did not end here. She had to serve in a rural school as a teacher for 3 years, and continued her services till she joined Hujur Paga School, Maharastra. Anutai kept bearing the burden of her domestic responsibility with enthusiasm. She devoted a prolonged phase of her life in the service of the rural people. Anutai's encounter with Tarabai Modak in 1945, was the turning point of her life. This camp was organized for women village workers. Tarabai had a plan to start an experimental pre-primary school in a rural area. Thereafter began a historical partnership between the two women leading education to its summit, which lasted till the death of Tarabai's in 1973. The Gram Bal Shiksha Kendra started by them at in 1945, became a gamut of exploratory ventures, new ideas, innovations and experiments to be ever taken up in education. These were all neatly and accurately intertwined to the problems and needs of the under-privileged children. Presently Anutai chairs the position of Director of Gram Bal Shiksha Kendra. She is the Secretary of the Nutan Bal Shikshan Sangh, the parent body.

The amazing concepts of Anganwadi, Balvad, and Kuran Shala was born out of Anutai's dynamic thought. She had already applied her ideas in the tribal areas of Thane District of Maharashtra. Her concepts have been recognized and credited 
as useful and innovative concepts in the development of education, its application and methods in this country. Her efforts have no doubt revolutionized the Indian system of pre-school learning. Tarabai and Anutai met with several problems and challenges, since the tribal people did not agree to move towards education. Anutai was able to overcome these challenges by her patience and determination, which further managed to constitute the supreme foundation of a new and methodical system of education. The new system of education was designed to meet the needs of the tribal. This took her appreciation to a larger domain.

She was of the view that there is an immeasurable spiritual strength which lies hidden in a woman. Therefore we should provide all possible efforts to awaken the women community. Numerous Mahila Melawas are organized where importance of Health and Hygiene, Nutrition, Cottage Industries, Family Welfare Programmes, Evil Effects of Superstitions, Social Education and Child Care is tried to make women understand through various means of community contact. She started a school for the Dumb and Deaf in June 1980 for the poor children. Anutai is the editor of a Marathi Magazine Shikshan Patrika. In 1983, Anutai started an amazing project named Gram-Mangal.Shecredits her success to Tarabai Modak and fully acknowledges her debt to her, who had inspired her. She has been honored with several awards by the Government of India looking after her contributions towards education and society.

\section{PANDITA RAMABAI}

Pandita Ramabai (23 April 1858-5 April 1922), daughter of Anant Shastri and Lakshmibai, was born in Madras Presidency. Anant Shastri, though an intellectual Brahmin, was progressive enough to stand against the superstitions of the Hindu traditions and educated her. By the age of 12, Ramabai had already learnt 18000 Verses from Puranas. Ramabai was taught various Indian languages like,
Sanskrit, Marathi Bengali, Kanarese and Hindi. Ramabai married Bipi Medhavi in 1880, belonging from a much lower cast. Ramabai converted herself to Christianity after she went to England, receiving a scholarship in 1883 , to be a trainer there.

After the death of her husband in 1882, she moved to Pune, where she founded Arya Mahila Samaj. This Samaj promoted the women's causes, education and freedom from the oppressive child marriage. Ramabai established Sarda Sadan and The Mukti Mission (1889) in Pune. Both of these acted as a refuge for widows who were abused and deserted by their families. She also started Sharda Sadan, which provided education, housing, medical services and vocational training for the needy people which consisted of orphans, widows and blinds. "These famine-striken, neglected children and older widows were not ready for the high-school work which the pupils of the Sharada Sadan were taking, and it was therefore necessary to begin industrial work. From that time on this has been a noted feature of the great establishment. Not only is the cooking for this large number done by the girls, but the weaving of their clothing is carried on in a number of low buildings, where the cotton is carded, spun, and dyed, and then woven into the neat saris (dresses) for the large establishment." (Butler, C. p.58).

The Pandita Ramabai Mukti Mission is still active today which provides facilities to the needy.

- Awards and Honours

1. The titles 'Pandit' and 'Sarswati' were bestowed on her at Bengal after recognizing her skill in Sanskrit.

2. Kaisar-i-Hind medal awarded for community service in 1919.

3. Govt. of India issued a commemorative stamp in 1989, recognizing her contribution to the advancement of women. 


\section{NAWAB BEGUM SULTAN KAIKHUSRAU JAHAN}

Begum Sultan Kaikhusrau Jahan (9 July 1858 - 12 May 1930) is notable for her progressive works and reigning as the Begum of Bhopal from 1901 to 1926. Begum Sultan Kaikhusrau Jahan was the only surviving child of General HH Nasir ud-Daula, Nawab Baqi Muhammad Khan Bahadur and Nawab Begum Sultan Shah Jahan and. Begum Sultan was a great reformer following the tradition of her mother and grandmother. She established many pivotal educational institutions in Bhopal. She was the one to establish free and compulsory primary education in the year 1918. She particularly focused on female education. Begum Sultan established many schools and technical institutes which helped in increasing the number of qualified teachers. She was the founding Chancellor of Aligarh Muslim University from 1920 till her death and she remains to be the only lady Chancellor who served the university. "After coming to the throne, Sultan Jahan Begum promoted the social and educational reforms especially for women. As a campaign of social reforms, she toured the villages and listening the problems faced by the womenfolk. She paid special attention to improve the health of women and children and established two hospitals in Bhopal state i.e., Prince of Wales hospital for males and Lady Lansdowne hospital for females which later was known as Sultania Zenana Hospital." (Islam, 2014)

Begum Sultan laid her attention towards women education. Begum was a strong supporter of Mohammad Girls School of Aligarh. There was an urgent need for the management of Girls school, but lacked funds. Her attention in developing proper curriculum for women education was remarkable. She was the one to propose the idea of Home science in the curriculum. During her visit to Aligarh in 1915, she laid the foundation stone for girl's hostel and inaugurated the Girls School building. "Her Highness mentions in her account that the state was spending a sum of ten thousand rupees every year on scholarship and those scholarships were given to assist students to qualify themselves in medicine, engineering, agriculture, law, and other sciences or to enable them to proceed to Europe for more advanced study $x l v i$. In the year 1912 the report of state budget cleared the fact that every year the amount of one lakh rupees spend on education and ten thousand rupees for scholarships." (Islam, 2014)

She chaired the President of the AllIndia Muslim Ladies' Association in 1914. Begum Sultan authored several books on health, education and other topics, which included Tandurusti, Hidayatuz-Zaujan, Bachchon-ki-Parwarish, Sabil ul-Jinan, Maishat-o-Moashirat, Hidayat Timardari etc. She received numerous awards for her services to the society. In 1926, Begum Sultan abdicated the throne to Hamidullah Khan, her youngest and the only surviving son.

\section{DURGABAI DESHMUKH}

Durgabai Deshmukh (15 July 1909-9 May 1981) born in Rajahmundry, participated in the Non-Co-operation Movement during the Indian Independence. She was influenced by the ideals of Gandhiji and propagated his ideals. She established schools to train women in spinning and weaving. Durgabai Deshmukh established Andhra Mahila Sabhain 1936, to coach young Telugu girls of Madras who were willing to appear for the Matriculation examination of the Banaras Hindu University and soon the organization became a great institution of social welfare and education. She gathered funds for the institution. Andhra Mahila Sabha trained women to excel in various activities like teaching, nursing and journalism. Andhra Mahila, a monthly Telegu journal was founded and edited by Durgabai, which attracted the attention of Pt. Jawaharlal Nehru willing utilize her services at the national level.

Durgabai's services were utilized completely at the national level. She became 
the Chairwoman of Central Social Welfare Board, National Committee on girls' and women's education and National Council for Women's Education. She was also a Member of Parliament and held a position at the Planning Commission and The Andhra Educational Society, New Delhi. Durgabai Deshmukh was awarded the Fourth Nehru Literary Award in 1971 remembering her outstanding contribution to the promotion of education in India. She was also awarded Padma Vibhushan in 1975.

\section{PANDITA BRAHMACHARINI CHANDBAI}

Pandita Brahmacharini Chandabai (1880-1977) a Jain scholar is considered and valued to be one of the pioneers of women's education in India. Chandabai was the founder of the oldest women's publication, which still continues to publish in India, Jain Mahiladarsh. Chandabai studied and was deeply interested in the classical subjects which included Prakrit, Sanskrit, nyāya (logic), literature and grammar, dharmaśāstra etc. The title Panditawas bestowed on her from Kashi. In 1907 she established a school for girls, which later came to be known as The Jain Balasharm. She also became the director of The Jain Balasharm in 1939.

Chandabai often served sick students at The Jain Balasharm. She started and edited a magazine, Jain Mahiladarsh in 1921. She wrote several books including Updesh Ratna Mala, Nibandh Darpan, Nibandh Ratna Mala, Adarsh Kahaniyan, Saubhagya Ratna Mala and Adarsh Nibandh.

\section{CONCLUSION}

The role of these women, promoting social causes are noteworthy. They emerge as identities of national hope. They helped, supported and promoted the causes of a large number of middle-class, rural and tribal women who were in strict need of care and education. These path breaker women not only helped in promoting education but also contributed and arranged the funds needed for education. While we can credit Tarabai Modak for her eminent contributions towards engaging new methods for pre-school students and providing shelter and care for the orphans and widows, and hence aptly credited as the Montessori Mother, while others, Durgabai Deshmukh, Anutai Wagh, Pandita Ramabai, Pandita Brahmacharini Chandbai, Nawab Begum Sultan Kaikhusrau Jahancan be credited for not only promoting education but also for uplifting the status of women in India.

\section{Acknowledgement: None}

\section{Conflict of Interest: None}

\section{REFERENCES}

1. Ambujammal, S. (1962). Social Welfare and Smt. Durgabai Deshmukh, Andhra Mahila Silver Jubilee Souvenir.

2. Anderson, A. (2006). Pandita Ramabai, the Mukti Revival and Global Pentecostalism, SAGE Journals.

3. Asthana, P. (1974) Women's movements in India, Vikas Publishing House, Delhi.

4. Bhosale, J. and Vaidya, M. (Ed), (2013) The making of Modern India, Shabdali Publication, Pune.

5. Butler, C. (1922). Pandita Ramabai Saraswati, Pioneer in the Movement for the Education of the Child-widow of India, Fleming H. Revell Company, London and Edinburgh

6. Deshmukh, G. (1957). Education for Girls and Women. The Social Welfare, Vol.IV.

7. Gupta R. and Durgesh, N. (2006). University News: Education of the Disabied A case study.

8. Forbes, G. (2008). The New Cambridge History Of India: Women In Modern India, Cambridge University Press. UK.

9. Hurley, S.L. (2007). Muslim Women, Reform and Princely Patronage: Nawab Sultan Jahan Begam of Bhopal, Royal Asiatic Society Books, Routledge, London.

10. Islam, T. (2014). Social and Educational Reforms of Nawab Sultan Jahan Begum. The International Journal Of Humanities \& Social Studies. 
11. Jaiswal, V. and Kumar, A. (2010). University News: Students Perception of quality higher. Education, A case study.

12. Kosambi, M. (ed) (1889). Pandita Ramabai's American Encounter: The Peoples of the United States. Indiana University Press. US

13. Meyer, D.S. et al (2002). Social Movements: Identity, Culture, and the State, Oxford University Press. NY

14. Mukti Prayer Bell, centenary Edition (18891989), 1989.

15. Pandita, R. (1887). The High Caste Hindoo Woman, The Women's Teperance publication Philadelfia, America.
16. Pandita, R. (1907). T Testimony, Mukti Mission, Kedgaon.

17. Punde, R. (May 2006). Muslim Women \& Girls Education- A Case Study, Journal of Indian Education from Hydrabad.

18. Schneir, M. (ed). (1972). Feminism: The Essential Historical Writings, New York, Vintage. P.xiv.

How to cite this article: Adhikari A, Saha B. Lesser known Indian women educators and reformers. International Journal of Research and Review. 2021; 8(9): 442-447. DOI: https://doi.org/10.52403/ijrr.20210956 